\title{
Efficacy of rights-based management of small pelagic fish within an ecosystems approach to fisheries in South Africa
}

\author{
M. M. Hara
}

\section{Abstract}

South Africa's small pelagics fishery is moving towards a management strategy using an ecosystem approach to fisheries (EAF), with rights-based management (RBM) as the key rights allocation system. While EAF strives to balance between, among others, ecological and social-economic objectives, RBM is driving the sector towards economic efficiency. Within EAF itself, there are still underlying mismatches between the two top objectives, 'human wellbeing' and 'ecological wellbeing', in effect requiring a better balance between these objectives than there is currently. For example, fishers do not believe they should be competing with marine mammals and birds for allocation of the resource, yet this is one of the primary trade-offs that have to be made when setting the annual total allowable catches (TACs) under EAF. A balance between the two objectives could be achieved through acceptable trade-offs between them among all stakeholders within inclusive governance. Implementation of RBM has had both positive and negative effects on the objectives for EAF. Of concern are the negative effects of RBM on human wellbeing. For example, fishers feel that RBM has weakened their bargaining position, thereby reducing their benefits. In addition, RBM has resulted in job losses and insecurity of employment within the fisheries sector. The most affected have been the most vulnerable - the low level workers - who ought to be the key beneficiaries of RBM. Thus prioritising and protecting vulnerable groups and fishing communities need careful consideration when creating RBM, even in the context of EAF. Rights-based management has also had negative effects on ecological wellbeing through practices such as increased dumping and 'high grading' as part of industry's drive for increased efficiency under RBM. Whereas scientists believe that variability is largely due to environmental conditions, fishers strongly feel that dumping, high grading and high fishing pressure are the main factors. One of the positive aspects of RBM has been improved understanding among rights-holders and fishers of the need to consider other organisms in the TAC and to protect these through establishment of marine protected areas, island perimeter closures and limiting bycatch, thereby impacting positively on ecological wellbeing.

\section{Introduction:}

South Africa's fisheries policy is founded upon the constitutional principle that all the country's marine resources are a national asset and the heritage of its citizens that should be managed and developed for the benefit of its present and future generations (Marine Living Resources Act No. 18 of 1998, RSA 1998a; White Paper: 
marine fisheries policy, DEAT 1997). Although the fisheries sector contributes < $1 \%$ (approximately $0.6 \%$ in 2008) 1 to South Africa's gross domestic product, the policy objectives recognise the need for the sector to improve its overall contribution to the country's long-term vision of a democratic South Africa, inter alia: a competitive, fast-growing economy that creates sufficient jobs for all work-seekers; redistribution of income and opportunities in favour of the poor; a society in which sound health, education and other services are available to all; and an environment in which homes are secure and places of work are productive (Department of Finance 1996). Following the protracted fisheries policy revision process (Hersoug 2002, Isaacs and Hara 2008, Hara and Raakjær 2009) that culminated in the enactment of the Marine Living Resources Act (RSA 1998a), the rights allocation policy evolved from annually renewable rights to medium-term rights for the period 2002-2005 and then to longterm rights (from 2006 onwards).

From 2006, the government of South Africa issued 15-year (2006-2020) long-term fishing rights for most of the commercial species including small pelagic fish. Long-term rights are a form of a rights-based management (RBM) approach. The overarching objectives that had been set by government for allocating long-term rights were: to maintain and improve the transformation of the fishing industry; to create an environment for attracting investment in infrastructure; job creation; encouragement of value-adding; reduction of bycatch; and generally to promote the economic viability and environmental sustainability of commercial fisheries (DEAT 2005a).

South Africa committed itself to introducing an ecosystems approach to fisheries (EAF) by 2010 (DEAT 2005a).

This followed the 2001 Reykjavik Declaration (FAO 2003) and the Johannesburg 2002 World Summit on Sustainable Development (UNCSD 2002), which urged countries to develop and implement national plans for maintaining or restoring fish stocks to maximum sustainable yield levels.

This study investigates the efficacy of RBM within the EAF for achieving both socioeconomic and bio-ecological objectives, which the commercial fisheries sectors are being increasingly asked to do. Questions that arise include: how is this contributing towards achieving government's policy objectives, and what is the impact on the resource, the rights-holders, the workers (especially vessel workers and factory workers), and, in effect, the fishing communities? The South African small pelagics sector is used here as the study case.

\section{Small pelagics}

South Africa's fishing rights for small pelagics are based on the exploitation of sardine Sardinops sagax and anchovy Engraulus encrasicolus, with associated bycatch for round herring Etrumeus whiteheadii and Cape horse mackerel Trachurus capensis. This sector is the biggest in terms of landed volume of fish and second only to hake Merluccius spp. in terms of value of landed catch. Sardine are mostly canned whereas anchovy are reduced to fishmeal, fish oil and fish paste. The sector is managed using operational management procedures (OMPs) (Fairweather et al. 2006, Butterworth 
2007, 2008, de Moor et al. 2011) that set annual total allowable catch (TAC) for anchovy and sardine, and associated bycatch for the other species. For the long-term rights, 109 entities have been awarded 15-year (2006-2020) rights (George Warman Publications 2007). In addition, the South African management system limits the number of vessels that can be deployed in the sector to about 100 (DEAT 2005b).

The west coast of South Africa has historically been the area in which small pelagics are available to fishers. Most of the sector's infrastructure - the fishing fleet, and major canning and fishmeal factories - is based on the West Coast, at Saldanha Bay, St Helena Bay and Velddrif. Coastal communities have settled in and around this area, largely based on derivation of employment from the fishing industry (van Sittert 2002, Isaacs 2003). In addition, a small fleet operates from Hout Bay in Cape Town and another from Gans Bay on the south coast of the Western Cape province. Nelson Mandela Bay is the base for the fleet exploiting the resource in the Eastern Cape province. Nevertheless, the mainstay of the small pelagic sector remains on the West Coast.

\section{Study approach}

This study was conducted on the West Coast in 2010 and 2011. The study was undertaken using semi-structured interviews with key informants and focus groups. In all, 23 individual interviews and four focus-group discussions (with the West Coast Pelagic Fishers' Association, a group of skippers and two crew member groups) were undertaken. The following categories of stakeholders were interviewed: fishing vessel skippers and crew members, rights-holders (both individual and representatives of companies) and employees of the Department of Agriculture, Forestry and Fisheries (DAFF): branch Fisheries Management. Where authentication of the authoritativeness of specific information is required, the system of 'personal communication' (pers. comm.) referencing has been used. A questionnaire was used as a guide for the interviews. The key list of questions was arranged under the following categories: changes in status of the fishery; resource assessment and monitoring practices; social and economic benefits from the fishery; structural organisation of fishers; employment opportunities; wider community benefits; and access and inclusion in decision-making, stewardship and governance arrangements.

\section{Rights-based fisheries management}

One of the key questions in fisheries management is whether creation of property rights could close open-access to fishing commons and thereby improve both bio-ecological and socio-economic management outcomes. The idea of property rights in fisheries is based on the idea of extending exclusive 'use rights' to fishers (OECD 1997, Christy 2000, Edwards 2000, Eythórsson 2000, Hatcher and Read 2001, Arnason 2005). Rights in a fishery define a claim to a benefit stream that is protected by law, and what particular actions a rights-holder is legally authorised to undertake in extracting the benefits (Bromley 1989). Property rights are supposed to provide for perpetuity, security, exclusivity and transferability (Hallowell 1943, Alchian and Demsetz 1973, Schlager and Ostrom 1992, World Bank 2004, Ostrom 2009) of a rights-holder's share in a fishery. This would presumably increase the value of the right and influence the behaviour of rights-holders, especially with regard to positive 
husbandry, incentives to invest in the industry and compliance with regulations, thereby improving the long-term biological, social and economic sustainability of the resource and the benefits (OECD 1997, Edwards 2000, Shotton 2000, Arnason 2005). Property rights are also intended to increase economic and social benefits for all direct industry participants (rights-holders and their employees), and society at large, through industry rationalisation and maximisation of economic efficiency (Christy 2000, Copes and Pálsson 2000, Edwards 2000, Eythórsson 2000, Arnason 2001, 2005).

For administrators and fishers, an initial and critical issue in RBM is the basis for eligibility for allocation of a right. The most common approach is 'catch history' (Copes and Pálsson 2000, Edwards 2000, Arnason 2005, DEAT 2005a). However, there are usually reasons to recognise that others without a fishing history should also be eligible for a right in a fishery. In South Africa's context, this is particularly pertinent due to the history of disenfranchisation of blacks from fishing rights under apartheid (Hersoug 2002, van Sittert 2002, DEAT 2005a, Raakjær Nielsen and Hara 2006, Isaacs et al. 2007). In addition, allocations should be considered for skippers, processing factory workers and fishing communities. The question of equity therefore generally arises with regard to the allocation of exclusive use rights as property rights define who can and cannot participate in the fishery, especially given that decisions about allocation of use rights may be very difficult to reverse once rights have been allocated (Eythórsson 2000).

Two basic approaches are used to create property rights under RBM - individual transferable quotas (ITQs) and licensing limits (OECD 1997, Hatcher 2005). Under the former approach, the annual allowable catch is divided into shares, which are distributed among the eligible rights-holders. The limited licensing system generally tries to limit access to a fishery by limiting the number of vessels. South Africa uses a combination of both approaches for most commercial species including small pelagics; long-term rights-holders have a fixed proportion of the annual TAC for the duration of those rights and there is a maximum of 100 vessels allowed in the sector.

\section{Ecosystems approach to fisheries}

Fisheries management has generally been based on single-species management through limitation of the volume of fish of a specific species that can be harvested to ensure sustainable utilisation. It is now recognised that fishing can have substantial impacts on the broader marine environment - through alteration of the benthic habitat, foodwebs and the biodiversity of marine communities - in addition to the target species (Pitcher and Lam 2010).

Fishing is only one use of the marine ecosystem and society can benefit from many other uses. These include other commercial (e.g. tourism, mineral and oil extraction, shipping and energy generation), cultural, social and non-consumptive uses, which are being recognised increasingly through 'marine spatial planning' initiatives in Europe (Ounanian et al. 2012). Consideration must therefore be taken of other competing uses, social and economic values to society and the requirements of other organisms in the ecosystem. Fisheries policy decisions should account for all these aspects. 
Ecosystems approach to fisheries is recognised as the integrative governance framework that combines conventional fisheries management and ecosystem management (FAO 2003). Ward et al. (2002) defined EAF as 'an extension of conventional fisheries management recognizing more explicitly the interdependence between human well-being and ecosystem health and the need to maintain ecosystems' productivity for present and future generations' (quoted in FAO 2003, p 6).

South Africa introduced an EAF in 2002 (Shannon et al. 2004, DEAT 2005a, 2005b, Petersen et al. 2010). The policy for the allocation and management of small pelagics (DEAT 2005b, p 14) states that 'the fishery shall be managed in accordance with the EAF approach'. The policy defines an EAF as 'a holistic and integrated policy which recognises that fishing and various land-based activities impact on the broader marine environment' (DEAT 2005b, p 14). The policy would include, among others, protection of ecosystems, elimination of destructive fishing practices, establishment of marine protected areas (MPAs) and protection of nursery grounds during fish spawning periods (DEAT 2005a).

Following a series of multi-stakeholder workshops to conduct ecological risk assessments for all the major commercial species, hierarchal trees of the main components of the EAF in South Africa were developed (Paterson and Petersen 2010, Petersen et al. 2010). The generic tree, adapted from FAO (2003), has three main components, namely ecological wellbeing, human wellbeing and ability to achieve (Paterson et al. 2010, Petersen et al. 2010). Currently, the ecological risk assessment approach remains the only formal implementation mechanism for EAF in South Africa (Paterson and Petersen 2010).

\section{Conceptual framework for study}

This study uses seven key performance indicators of RBM in South Africa's small pelagics industry: transformation, investment in infrastructure, job creation, reduction of bycatch, economic viability, environmental sustainability and management stability (DEAT 2005a, DAFF 2012). The general EAF framework adapted by Petersen et al. (2010) for South Africa (ecological wellbeing, human wellbeing, and ability to achieve) was used to analyse the efficacy of RBM within this ecosystems approach.

\section{Rights-based fishing in an ecosystem approach setting}

This section presents the findings from interviews and from secondary sources.

\section{The bundling of rights by processing factories}

Historically, quotas were issued to factories while catching rights were awarded to vessel owners, who in most instances skippered their own vessels. The factories therefore had to contract out the catching of their quota to vessel owners. Up to $80 \%$ of the catching was done on this basis (F Tolken and H Smit, West Coast Pelagic Fishers' Association, pers. comm.). Factories therefore sought the most skilled skippers and crew to catch the factory quota. One of the conditions for awarding medium- and longterm rights had been the need for rights-holders to demonstrate commitment to the industry through investment. Thus, increasingly, factories bought their own vessels. Currently, most processing companies have a quota, vessels for harvesting their 
quota and a processing factory. Therefore, factories mainly use their own vessels to harvest their quota. Although independent vessel owners can obtain their own quotas, these might be too small to make the vessel viable without catching contracts. The contracts with factories and/or rights-holders without vessels are thus still vital for the economic viability of independent vessel ownership. It was due to increased lack of viable catching contracts with factories that most independent vessel owners sold their vessels and moved out of the industry in the 1990s and 2000 . Those who remained in the industry without vessels work for the factories as independent skippers (F Tolken and H Smit pers. comm.). Unlike the arrangement on the West Coast, the old agreement still exists on the South Coast between the Gans Bay Marine processing company (which has a quota but no vessels) and independent vessel owners. The quota is caught by independent vessel owners who are paid a catching fee that is agreed upon between the factory and the vessel owners (A Coetzee, Gans Bay Marine, pers. comm.).

\section{Structure of employment and employee benefits}

The skipper recruits his own crew, even when he is contracted by a factory to fish using a factory vessel. The factory has no contractual obligations to the crew members and is thus shielded from any labour issues or disputes with them ${ }^{2}$. Whereas the contracts with vessel owners and skippers were for one year in the past, these are increasingly structured as seasonal contracts in line with the fishing season and fish availability (H Smit pers. comm.).

In terms of remuneration, skippers and crew members are paid a proportion of the value of the catch, based on the fishmeal price or the raw fish price for sardine, which varies between $4.8 \%$ and $5.1 \%$ (L Strydom, West Coast Pelagic Fishers' Association, pers. comm.). In the past, the Fishmeal Producer Association determined and published the average fishmeal price, which skippers and crew members could use to determine what constituted their share of the benefits from the delivered catch. Unfortunately, the association does not publish this price anymore, following the bread-price fixing3 case that the South African Competition Commission had against producers, some of which are part of the group of companies with shares in the fishmeal industry. The association thus stopped publishing the average price for fishmeal to guard against falling foul of anti-competitive regulations with the Competition Commission. As a result, there is no longer a third-party mechanism to arbitrate the price between factories and the skippers/crew members. The price is negotiated between the individual factories and the skippers/ crew members. The fishers pointed out that because they worked for factories or delivered their catch to the individual factories, they are 'price takers'.

Once the skippers and crew members receive their proportion of the value of the catch based on the fishmeal or raw fish price, this is shared among them, according to agreed proportions. The proportions among the skippers and crew members on most vessels are as follows: skipper (24.22\%), mate (11.11\%), driver (11.11\%), crew members (53.56\%).

In addition to this basic pay, the skippers and crew members receive incentive bonuses on a sliding scale based on quality of fish. For sardine, the bonuses are based on a 
premium-quality sliding scale based on the number of cartons produced per tonne of fish (L Strydom pers. comm.).

\section{Marine protected areas, island perimeter closures and consideration of birds and marine mammals in the TAC}

An important aspect of the EAF policy and related legislation is the requirement for consideration of organisms affected directly or indirectly within the marine environment. The Sixteen Mile Beach MPA was established in this context (Wood 2007). In addition, the MPA overlaps with the 10.8 nautical mile radius around Dassen Island within which purse-seine fishing had been prohibited for three years to accommodate a feasibility study aimed at the conservation of African penguins Spheniscus demersus (DEAT 2008). The introduction of island perimeter closures and the MPA is aimed at leaving space for marine birds and mammals to thrive and also for fish to breed without interference. In addition, consideration has to be given to how much of the small pelagics resource should be left for seals, seabirds, penguins and other living organisms when determining the TAC (e.g. Cury et al. 2011).

The fishers maintain that the strict enforcement of the Sixteen Mile Beach MPA notake zone has affected their catches, because the best catches used to be taken in this area. The skippers estimated that this has resulted in an annual loss of between 30 ooo and 50 ooo t of good-quality sardine.

\section{Variability, competition with marine mammals and high grading}

The fishers interviewed had the historical knowledge and experience that variability in abundance is characteristic of the pelagic resource, a notion that has been supported by scientific research (Fairweather et al. 2006, Hutchings et al. 2009, van der Lingen et al. 2011). In addition, there is strong evidence to show that there was a shift in the relative availability of fish from the West Coast to the South Coast during some years of the first decade of the millennium (Fairweather et al. 2006). The resource, however, appears to have shifted back recently, resulting in a larger proportion of its standing stock being caught in its traditional fishing grounds on the West Coast (van der Lingen et al. 2011). For most fishers, the threats to sustainability of the resource are twofold; the increasing seal population - because, in their opinion, seals take a considerable proportion of the resource4 - and dumping, which fishers consider is common practice. The fishers considered that dumping of fish (high grading) was partly influenced by the fact that factories require a minimum size of sardine that is suitable for canning (about $14 \mathrm{~cm}$ ). Also, factories have a maximum limit of fish volume that they can take delivery of, based on a plant's processing capacity. The skippers and their crews therefore have to ensure that they catch the right size and volume of fish for delivery.

\section{Number of vessels}

The number of operational fishing vessels in the sector has declined by nearly onethird in the past decade, mainly as a result of most independent vessel owners leaving the industry. Also, factories have been buying new and bigger boats following the assurance of being granted medium- and long-term rights. Further, owners have been replacing their old wooden vessels, which normally did not have 
refrigeration facilities, with larger, more fuel-efficient steel or fibre glass vessels with refrigeration systems. The maximum number of vessels allowed in the sector is about 100 (DEAT 2005b). The number of vessels operating at any given time is largely influenced by the annual quota size; for example, only 71 vessels were declared operational for the 2011 season on the permits issued ( $\mathrm{J}$ de Goede, DAFF, pers. comm.). According to the interviewees, the increased use of more efficient, mechanised vessels and fewer vessels has resulted in loss of jobs for skippers and crew members.

\section{Stewardship (co-management) of the resource and sector}

In the small pelagics sector, each fishing zone has a sea management committee (SMC), comprising local stakeholders (skippers, factory managers and DAFF fisheries monitoring control and surveillance inspectors). The SMC has powers to initiate discussion and propose temporary closure of an area if the size of the fish being caught is below the $14 \mathrm{~cm}$ minimum size required for canning. The committee also enforces such closures among its members. In this sense, the SMC is a rights holder-based management organisation that takes action bottom-up in liaison with the state authorities. The department (DAFF: branch Fisheries Management) also has a system whereby observers are placed on a number of randomly selected vessels to collect (mainly) biological data.

At the national level, the Small Pelagics Scientific Working Group (SWG) and the Resource Management Working Group (RMWG) are the formal governance structures for the sector where government scientists, representatives of stakeholder groups and non-governmental organisations discuss scientific and management issues and make recommendations to the Deputy Director General DAFF for final decision (Nyikahodzoi et al. 2010). Some of the key recommendations that are made by the SWG concern the TAC for the coming year, a revision of the TAC after a mid-year survey and other scientific issues. The RMWG is the body where distribution of rights and operational management issues are discussed. Not all rights-holders and fishers (skippers and crew members) belong to stakeholder associations and consequently they do not have representation on the working groups5.

\section{Efficacy of RBM within an EAF}

The assumption under an EAF is that improved species and environmental sustainability (ecological wellbeing) through stable and assured rights should result in increased social and economic benefits (human wellbeing). Hence RBM should lead to an increased incentive on the part of fishers to ensure the improved productivity and sustainability of the resource and ecosystem that forms the bedrock of revenue generation. Inclusive stewardship by all concerned stakeholders should increase the system's general 'ability to achieve'. Rights-based management should thus enhance the potency of EAF and result in increased wellbeing of the marine resource system in question and the dependent human society. The question is whether this is indeed the case when viewed from the perspective of South Africa's small pelagics sector.

\section{Bargaining position of vessel workers}

Given that most of the sardine caught are canned and the anchovy are reduced into fishmeal and fish oil, the processing right (through ownership of canning and fishmeal 
factories) is probably the key and controlling deterministic right in the sector. The bundling of rights by processing factories has strengthened their negotiating position and at the same time weakened that of skippers and the crew, independent vessel owners and independent quota-holders. The increased ownership of vessels and/or the upgrading of existing vessels by factories have further strengthened their negotiating and bargaining position. In particular, the processing right gives the factories considerable leverage in terms of the price they would be willing to pay for the delivered catch. Hence the skippers and crew members, independent vessel owners and independent quota-holders from the West Coast felt that the new rights-holding system had disadvantaged them greatly and that overall the current structure and system of rights allocation under RBM had reduced their benefits, thereby negatively affecting the human wellbeing objective under EAF.

\section{Security of employment}

Rights-based management has not changed the historical organisation of the catching sector, whereby the skipper sources, selects and employs his own crew. Even in situations in which a skipper is contracted to fish for a factory using a factory vessel, this arrangement remains unchanged. Thus the vessel owner, unless the skipper is the vessel owner, has no employer responsibilities towards crew members. To minimise potential labour relations problems, the skipper will not usually employ crew members belonging to labour unions. These 'casual labour' employment practices are contrary to the Labour Relations Act (Act No. 66 of 1995; RSA 1995) and the Basic Conditions of Employment Act (Act No. 11 of 2002; RSA 2002), which stipulate that anyone who has been employed for more than three months continuously qualifies as a permanent employee (Hara 2009). The insecurity of employment for crew members and the benefit sharing schemes based on amount and quality of catch are likely to increase the occurrence of high grading at sea in order to maximise earnings. RBM management has exacerbated the insecurity of employment among skippers and crew members and has also increased the likelihood of negative fishing practices among crew to the detriment of the resource, thus having negative effects on both EAF objectives of human wellbeing and ecological wellbeing.

\section{Community benefits}

For the rest of the local fishing communities on the West Coast the benefits from the sector are indirect, received as dependants of those employed in the sector (on the vessels and/or in the factories) or from multiplier effects and/or value chains such as wages spent by small pelagics industry employees on consumer goods and services. The purchase of bigger and more highly mechanised boats by the factories has resulted in fewer vessels and less crew members. The endeavour for increased efficiency also extends to factories, which in the past ran three shifts of eight hours each but now, in most cases, run only one shift of 12 hours per day, a 50\% reduction in total working hours6. The reduction in the number of people employed and the decrease in factory working hours means a decline in the level of benefits derived from the sector by workers (and therefore their dependants) and in the spread of benefits to the rest of the immediate community. In essence, although the sector might have become more operationally efficient and more profitable, the impact on low-level workers has been negative, in contradiction of the EAF objective of human wellbeing. 


\section{Fishing pressure and variability}

The introduction of RBM has not necessarily eradicated the competitive aspect within the fishing sector, i.e. catching the most and the best fish. This is especially pertinent in the small pelagics fishery where resource abundance is characteristically variable. Thus, the new, more efficient purse-seiners that the rights-holders have been investing in still present a challenge for sustainable fishing. The practice of under-reporting is still common. In addition, it is not clear whether the shift in geographic availability of the small pelagics from the West Coast to the South Coast over the past decade could be attributed to environmental changes or to fishing pressure on the West Coast (van der Lingen et al. 2011). Skippers strongly believe, however, that fishing pressure is a key factor in both variability and geographic shift and thus they support the notion that a closed season for a few months should be re-introduced. Fishers feel aggrieved that they now have to compete with seals, penguins and seabirds for quotas and for some of the prime fishing areas (through establishment of MPAs and island perimeter closures) as part of EAF.

\section{High grading}

Management of rights-holders has not solved the problem of dumping or high grading in the sector. Whereas dumping is one of the issues that EAF seeks to discourage, this practice is economically efficient as rights-holders want to land the size and quality of fish that will maximise their earnings (high grading). Bycatch limits, temporary area closures, island perimeter closures and MPAs, all supported by EAF, force skippers to fish farther from their fishing bases and factories, thereby increasing fishing operational costs, a situation that is not in line with the objectives of RBM.

\section{Balancing needs offishers and other organisms}

Within EAF, other marine organisms have been given greater recognition and protection - in terms of their food and other environmental requirements - than under previous, largely single-species approaches to fisheries management. Rightsholders have had to understand and accept this need for a balanced approach that takes cognisance of other organisms that interact with small pelagics when TACs are set and specific geographic areas are closed to fishing. Key to this acceptance has been consultative decision-making within the formal structures, namely SMCs, the SWG and the RMWG. Thus, EAF has increased awareness of competition for fish between fishers and marine organisms.

\section{Cooperative governance}

Confidence in a RBM management approach is supposed to be enhanced if rightsholders are directly involved in management decision-making. The question arises as to whether RBM has improved stewardship of the resource and the sector? The local and national co-governance structures ensure that the majority of stakeholders have structured and regular contact with each other. Although the views and inputs of rightsholders and fishers are supposed to be advisory, they carry weight in the sense that these are based on long-term and practical knowledge of the fishery and up-to-date experience of what is happening at the catching and operational level (Fairweather et al. 2006). The general view among most rights-holders and fishers is that government is generally very responsive to their views and interests, although this has not been the 
case on occasions. For example, the proposal by skippers and crew members for the reintroduction of a November-December annual closed season7, as well as the complaint by the fishers regarding the reduced catches of good sardine from the West Coast area as a result of the Sixteen Mile Beach MPA being declared no-take, did not yield positive results. Despite these examples, the general feeling among the fishers was that the functions of the SMCs, the SWG and the RMWG ensure that the fishery is managed in a consultative and cooperative manner. The key concern under the current system is that socio-economic factors are not adequately included in the OMP, since this remains a tool that mainly uses biological and ecological inputs (Fairweather et al. 2006). In a fully operational EAF, all components of the ecosystem, including human (social and economic) factors, should be taken into account.

\section{Summary and conclusions}

The following questions arise: has the RBM system resulted in increased ecological wellbeing for the resource and marine environment; has it resulted in improved human wellbeing for the sector workers and immediate community; and has it resulted in an enhanced ability to achieve for the sector? A number of conclusions can be drawn from this study regarding effects of implementing RBM within an EAF:

1. Fishers feel that the current structure and system of rights allocation under RBM has weakened their bargaining power when dealing with factories, resulting in reduction in their benefits. In addition, the new rights system has exacerbated their insecurity of employment. In this context, the structure of rights, and the benefits thereof under RBM,

1. negatively affect EAF's human wellbeing objective.

2. The reduction in the number of jobs, both on vessels

3. and in factories, as a part of the drive for increased efficiency under RBM, has meant a decline in the overall level of benefits derived from the sector for workers, their dependants and the coastal communities that largely thrive and depend on the fishing industry. On the whole, whereas the sector might have become more operationally efficient and improved its profitability, the impact on human wellbeing for low-level workers and their communities has been negative.

4. Dumping and high grading are practices that are reported still to be prevalent in the sector and stakeholders felt that RBM has not necessarily solved this problem. The benefit-sharing schemes based on quality of catch encourage these tendencies among skippers and their crew as a way of maximising their earnings. In addition, practices of under-reporting are still prevalent. While all these practices are economically efficient within rights-based fishing, they are negative when viewed under EAF's objective of ecological wellbeing.

5. Variability, both in geographic availability and abundance of the small pelagic fish resource, remains one of the key problems in the sector. Whereas scientists largely attribute this variability to environmental conditions, fishers strongly believe that fishing pressure is a key factor. If correct, their view that re-introduction of a closed season and continued self-regulation through the SMCs could have a positive impact on variability. 
6. EAF has increased the awareness and acknowledgement of competition for fish between fishers and marine predators, although fishers believe they should be given preference in terms of allocation of the resource. Bycatch limits, temporary area closures, island perimeter closures and MPAs, as part of EAF, force skippers to fish farther away from their fishing bases and factories, thereby increasing fishing operational costs, which is one aspect that RBM aims to reduce.

7. Although the views and inputs of rights-holders and fishers within the consultative and cooperative governance structures (SWG and RMWG) are supposed to be advisory, the general feeling is that government responds positively to their opinions and interests. Thus fora exist within RBM where alternative views that arise as a result of EAF can be discussed and debated, and consensus reached. The key concern among some stakeholders regarding inclusive governance is that the OMP does not adequately include social and economic factors in its computation of scientific advice. In a fully functioning EAF operationalised by OMP, all components of the ecosystem, including human (social and economic) factors, need be taken into account. Inclusion of social and economic factors in the OMP could hopefully reduce the negative effects of RBM on human wellbeing.

\section{Acknowledgements}

The research for this is article was carried out as part of the 'Defragmenting Resource Management in Southern Africa' (DARMA) project (AFS/2009/219017) funded by the European Union through the African Caribbean and Pacific (ACP) Science and Technology Programme (Europe Aid/127860/D/ ACT/ACP). The contents of this article are the author's sole responsibility and can under no circumstances be regarded as reflecting the views and position of the European Union. I thank all the interviewees that availed themselves for the research and gave consent for the information and insights they provided to be used for this publication, and colleagues and all the reviewers who gave critical advice on drafts of the manuscript. 


\section{References}

Alchian A, Demsetz H. 1973. The property rights paradigm. Journal of Economic History 33: $16-27$.

Arnason R. 2001. A review of international experiences with ITOs. CEMARE Report 59. Portsmouth: Centre for the Economics and Management of Aquatic Resources, University of Portsmouth.

Arnason R. 2005. Property rights in fisheries: Iceland's experience with ITQs. Reviews in Fish Biology and Fisheries 15: 243-264. Bromley D. 1989. Property relations and economic development: the other land reform. World Development 17: 876-877.

Butterworth DS. 2007. Why a management procedure approach? Some positives and negatives. ICES Journal of Marine Science 64: 613-617.

Butterworth DS. 2008. Some lessons from implementing management procedures. In: Tsukamoto K, Kawamura T, Takeuchi T, Beard TD, Kaiser MJ (eds), Fisheries for global welfare and environment: memorial book of the 5th World Fisheries Congress 2008. Tokyo: TerraPub. pp 381-397.

Christy FT. 2000. Common property rights. An alternative to ITQs. In: Shotton R (ed.), Use of property rights in fisheries management. Proceedings of the FishRights99 conference, 11-19 November 1999, Fremantle, Western Australia. FAO Fisheries Technical Paper 404/1. Rome: Food and Agriculture Organization of the United Nations.

Copes P, Pálsson G. 2000. Challenging ITQs: legal and political action in Iceland, Canada and Latin America. A preliminary overview. In: Johnston RS (ed.), Proceedings of the 1oth biennial conference of the International Institute of Fisheries Economics and Trade (IIFET), 10-14 July 2000, Corvallis, Oregon. Oregon: International Institute of Fisheries Economics and Trade. pp 1-6. Cury PM, Boyd IL, Bonhommeau S, Anker-Nilssen T, Crawford RJM, Furness RW, Mills JA, Murphy EJ, Österblom H, Paleczny M, Piatt JF, Roux J-P, Shannon LJ, Sydeman WJ. 2011. Global seabird response to forage fish depletion - one-third for the birds. Science 334: 1703-1706.

DAFF (Department of Agriculture, Forestry and Fisheries). 2012. 2009/10 Performance review of fishing right holders. Overall report/summary: limited commercial and full commercial rights holders. Cape Town: DAFF.

DEAT (Department of Environmental Affairs and Tourism). 1997. White paper: marine fisheries policy for South Africa. Pretoria: DEAT. Available at www.info.gov.za/whitepapers/1997/marine [accessed 4 December 2011].

DEAT (Department of Environmental Affairs and Tourism). 2005a. General policy on the allocation and management of long term commercial fishing rights, 2005. Unpublished Report. DEAT, Pretoria.

DEAT (Department of Environmental Affairs and Tourism). 2005b. Policy for the allocation and management of commercial fishing rights in the small pelagics (anchovy and sardine purse-seine) fishery: 2005. Unpublished Report. DEAT, Pretoria.

DEAT (Department of Environmental Affairs and Tourism). 2008. Section B. Permit conditions: pelagic fish (sardine/pilchard) fishery: 2008. Unpublished Report. DEAT, Cape Town.

de Moor CL, Butterworth DS, De Oliveira JAA. 2011. Is the management procedure approach equipped to handle short-lived pelagic species with their boom and bust 
dynamics? The case of the South African fishery for sardine and anchovy. ICES Journal of Marine Science 68: 2075-2085.

Department of Finance. 1996. Growth, employment and redistribution: a macroeconomic strategy. Pretoria: Department of Finance.

Edwards M. 2000. The administration of fisheries managed by property rights. In: Shotton $\mathrm{R}$ (ed.), Use of property rights in fisheries management. Proceedings of the FishRights99 conference, 11-19 November 1999, Fremantle, Western Australia. FAO Fisheries Technical Paper 404/2. Rome: Food and Agriculture Organization of the United Nations. pp 75-88.

Eythórsson E. 2000. A decade of ITQ-management in Iceland fisheries: consolidation without consensus. Marine Policy 24: 483-492.

Fairweather TP, Hara M, van der Lingen CD, Raakjær J, Shannon LJ, Louw GG, Degnbol P, Crawford RJM. 2006. A knowledge base for management of the capital-intensive fishery for small pelagic fish off South Africa. African Journal of Marine Science 28: $645-660$.

FAO. 2003. The ecosystem approach to fisheries: issues, terminology, principles, institutional foundations, implementation and outlook. FAO Fisheries Technical Paper No. 443. Rome: Food and Agriculture Organization of the United Nations.

George Warman Publications. 2007. Fishing industry handbook: South Africa, Namibia and Mozambique (35th edn). Cape Town: George Warman Publications.

Hallowell AI. 1943. The nature and function of property as a social institution. Journal of Legal and Political Sociology 1: 115-138. Hara M. 2009. Crew members in South Africa's squid industry; whether they have benefitted from transformation and governance reforms. Marine Policy 33: 513-519.

Hara M, Raakjær J. 2009. Policy evolution in South African fisheries: the governance of the sector for small pelagic. Development Southern Africa 26: 649-662.

Hatcher A. 2005. On the microeconomics of quota management in fisheries. Marine Resource Economics 20: 77-99.

Hatcher A, Read A. 2001. The allocation of fishing rights in UK fisheries. Case studies on the allocation of transferable quota rights in fisheries. In: Shotton $\mathrm{R}$ (ed.), Use of property rights in fisheries management. Proceedings of the FishRights99 conference, 11-19 November 1999, Fremantle, Western Australia. FAO Fisheries Technical Paper 411. Rome: Food and Agriculture Organization of the United Nations. pp 1-14.

Hersoug B. 2002. South African fishers on the road to equal access? - from "informal fishers" via "subsistence fishers" to "micro-commercial entrepreneurs". In: Hersoug B (ed.), Fishing in a sea of sharks: reconstruction and development in the South African industry. Delft: Eburon. pp 173-200.

Hutchings L, Roberts MR, Verheye HM. 2009. Marine fisheries monitoring programmes in South Africa. South African Journal of Science 105, March/April 2009: 94-102.

Isaacs M. 2003. Understanding the social processes and politics of implementing a new fisheries policy, the Marine Living Resource Act 18 of 1998, in South Africa. PhD thesis, University of Western Cape, South Africa.

Isaacs M, Hara M. 2008. Transformation in the South African fishing industry and its ability to redistribute fishing rights. In: Nielsen J, Dodson JJ, Friedland K, Hamon TR, Musick J, Verspoor E (eds), Proceedings of the fourth world fisheries 
congress (reconciling fisheries with conservation), 2-6 May 2004, Vancouver. Bethesda: American Fisheries Society. pp 687-703.

Isaacs M, Hara M, Raakjær J. 2007. Has reforming South African fisheries contributed to wealth redistribution and poverty alleviation? Ocean and Coastal Management 50: 301-313.

Jacobsberg I, Govender S. 2010. Fixing price fixing - South Africa (December 2, 2010). Eversheds, Johannesburg. Available at www.hg.org/article [accessed 24 January 2012].

Nyikahadzoi K, Hara M, Raakjær J. 2010. Transforming ownership and governance: lessons from capital intensive pelagic fisheries in South Africa and Zimbabwe. International Journal of the Commons 4: 663-682.

OECD (Organisation for Economic Cooperation and Development). 1997. Towards sustainable fisheries: economic aspects of the management of living marine resources. Paris: OECD.

Ostrom E. 2009. Design principles of robust property rights institutions: what have we learned. In: Ingram GK, Hong Y-H (eds), Property rights and land policies. Cambridge, Massachusetts: Lincoln Institute of Land Policy. pp 25-51.

Ounanian K, Delaney A, Raakjær J, Ramirez P. 2012. On unequal footing: stakeholder perspectives on the marine strategy framework directive as a mechanism of the ecosystem-based approach to marine management. Marine Policy 36: 658-666.

Paterson B, Isaacs M, Hara M, Jarre A, Moloney CL. 2010. Achieving transdisciplinary co-operation for EAF: a South African case study. Marine Policy 34: 782-794.

Paterson B, Petersen S. 2010. EAF implementation in southern Africa: lessons learnt. Marine Policy 34: 276-292.

Petersen S, Paterson B, Basson J, Moroff N, Roux J-P, Augustyn J, D’Almeida G. 2010. Tracking the implementation of an ecosystem approach to fisheries in southern Africa. Cape Town: WWF South Africa Report Series.

Pitcher T, Lam ME. 2010. Fishful thinking: rhetoric, reality, and the sea before us. Ecology and Society 15: article \#12. URL: http:// www.ecologyandsociety.org/vol15/iss2/art12/ (published online under license by the Resilience Alliance).

Raakjær Nielsen J, Hara MM. 2006. Transformation of South African industrial fisheries. Marine Policy 30: 43-50.

RSA (Republic of South Africa). 1995. Labour relations act (Act No. 66 of 1995). Government Gazette, South Africa 366 (16861).

RSA (Republic of South Africa). 1998a. Marine living resources act (Act No. 18 of 1998). Government Gazette, South Africa 395 (18930).

RSA (Republic of South Africa). 1998b. Competition act (Act No. 89 of 1998). Government Gazette, South Africa 400 (19412).

RSA (Republic of South Africa). 2002. Basic conditions of employment amendment act (Act No. 11 of 2002). Government Gazette, South Africa 444 (23539).

Schlager E, Ostrom E. 1992. Property rights regimes and natural resources: a conceptual analysis. Land Economics 68: 249-262.

Shannon LJ, Cochrane KL, Moloney CL, Freon P. 2004. Ecosystem approaches to fisheries in the southern Benguela: a workshop overview. In: Shannon LJ, Cochrane KL, Pillar SC (eds), Ecosystem approaches to fisheries in the southern Benguela. African Journal of Marine Science 26: 1-8. 
Shotton R. 2000. Use of property rights in fisheries management. Proceedings of the FishRights99 conference, 11-19 November 1999, Fremantle, Western Australia. Fisheries Technical Paper 404/1. Rome: Food and Agriculture Organization of the United Nations.

UNCSD (United Nations Commission on Sustainable Development). 2002. World summit on sustainable development (WSSD), 24 August to 4 September, Johannesburg. New York: UNCSD.

van der Lingen CD, Coetzee JC, Hutchings LF. 2011. Causes and effects of changes in the distribution of anchovy and sardine in shelf waters off South Africa. In: Zietsman L (ed.), Observations on environmental change in South Africa. Stellenbosch: SUN MeDIA. pp 252-257.

van Sittert L. 2002. Those who cannot remember the past are condemned to repeat it: comparing fisheries reforms in South Africa. Marine Policy 26: 295-305.

Ward T, Tarte D, Hegerl E, Short K. 2002. Ecosystem-based management of marine capture fisheries. WWF Australia.

Wood LJ. 2007. MPA Global: a database of the world's marine protected areas. Sea Around Us Project, UNEP-WCMC \& WWF. Available at www.mpaglobal.org/index [accessed 7 December 2011].

World Bank. 2004. Saving fish and fishers. Washington, DC: World Bank. 